\title{
Corrosion Behavior of Aluminium Metal Matrix Composite
}

\author{
Zaki Ahmad ${ }^{1}$, Amir Farzaneh ${ }^{2}$ and B. J. Abdul Aleem ${ }^{1}$ \\ ${ }^{1}$ Mechanical Engineering Department, \\ King Fahd University of Petroleum \& Minerals, Dhahran, \\ ${ }^{2}$ Department of Metals, International Center for Science, \\ High Technology and Environmental Sciences, Kerman, \\ ${ }^{1}$ Saudi Arabi \\ ${ }^{2}$ Iran
}

\section{Introduction}

Metal matrix composite (MMC) is a material which consists of metal alloys reinforced with continuous, discontinuous fibers, whiskers or particulates, the end properties of which are intermediate between the alloy and reinforcement (Schwartz, 1997). These materials have remained the focus of attention of aerospace, automobile and mineral processing industry because of the several advantages they offer which include high strength to weight ratio, elevated temperature toughness, low density, high stiffness and high strength compared to its monolithic counterpart (the original alloy). The particle reinforced metal matrix composites (PRMMC) satisfy many requirements for performance driven applications in aerospace, automobile and electrical industry. The particle reinforced composites can be tailored and engineered with specific required properties for specific application. The commonly used reinforcing materials are silicon carbide, aluminium oxide and graphite in the form of particles and whiskers. Nominal compositions of some well known alloys which are reinforced with whiskers, fibers or particulate is shown table 1. Figure 1 shows that microhardness increases with an increase in filler content of the composites.

\begin{tabular}{|c|c|c|c|c|c|c|c|c|c|}
\hline & $\mathrm{Si}$ & $\mathrm{Fe}$ & $\mathrm{Cu}$ & $\mathrm{Mn}$ & $\mathrm{Mg}$ & $\mathrm{Cr}$ & $\mathrm{Zn}$ & $\mathrm{Ti}$ & $\mathrm{Al}$ \\
\hline $\begin{array}{c}\mathrm{Al} \\
6061\end{array}$ & 0.62 & 0.23 & 0.22 & 0.03 & 0.84 & 0.22 & 0.10 & 0.1 & $\mathrm{Bal}$ \\
\hline $\begin{array}{c}\mathrm{Al} \\
7075\end{array}$ & 0.40 & 0.50 & 0.60 & 0.30 & 2.5 & 0.15 & 5.5 & 0.2 & Bal \\
\hline $\begin{array}{c}\mathrm{Al} \\
6013\end{array}$ & 0.6 & 0.50 & 1.1 & 0.2 & 0.8 & 0.1 & 0.25 & 01 & $\mathrm{Bal}$ \\
\hline
\end{tabular}

Table 1. Nominal composition of some well known alloys reinforced with whiskers and particles

MMC can be continuous or discontinuous. Discontinuous MMC can be isotropic and can be worked with standard metal working techniques such as extrusion, forging or rolling. 
Continuous reinforcement uses monofilament fibers, wires or fibers such can carbon fibers. The reinforcement materials commonly used are graphite $\mathrm{SiO}_{2}, \mathrm{SiC}, \mathrm{TiC}, \mathrm{Al}_{2} \mathrm{O}_{3}$ and glasses.

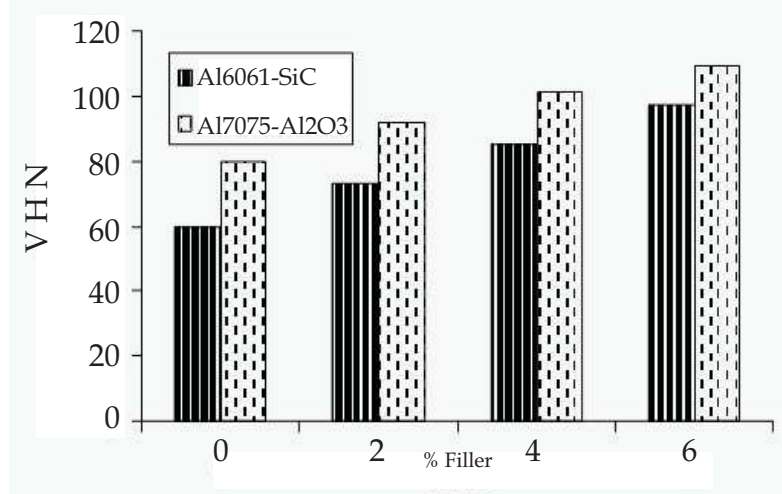

Fig. 1. Microhardness of Al6061-SiC and Al7075-Al2O3 composites (Vaeeresh et al., 2010)

\section{Mechanical and physical properties}

Metal matrix composites have been shown to exhibit significant improvements in certain physical and mechanical properties over their monolithic metallic counterpart, However, the mechanical properties are strongly dependent on micro structural parameters, in particular, size, shapes volume fraction and orientation of the particles and the composition of matrix.

\begin{tabular}{|c|c|c|c|c|}
\hline Parameters & $\mathrm{Al} 6061$ & $\mathrm{Al} 7075$ & $\mathrm{SiC}$ & $\mathrm{Al} 2 \mathrm{O} 3$ \\
\hline Flastic Modulus & $70-80$ & $70-80$ & 410 & 300 \\
\hline Density & 2.7 & 2.81 & 3.1 & 3.69 \\
\hline Poisson's Ratio & 0.33 & 0.33 & 0.14 & 0.21 \\
\hline Hardness (HB - 500 ) & 30 & 60 & $28 \mathrm{~W}$ & 1175 \\
\hline Tensile Strength(MPA) & 115 & 220 & 3900 & 2100 \\
\hline
\end{tabular}

Table 2. Properties of Al 6061 and Al 7075 with and without reinforcement

It is a general observation that the Vickers microhardness observed is greater than the matrix alloy. This is a exemplified by composites, 6061/SiC(p), $6013 \mathrm{SiC}(\mathrm{p})$ and 7075/Al2O3(p) Figure 1 shows the effect of Vol.\% of particulates $(\mathrm{SiC})$ on the modulus of elasticity of $\mathrm{Al} 6061$ / SiC, and Al 7075/ Al2O3 composites (Vaeeresh et al., 2010).

The development of metal matrix composites has been a major breakthrough in the last twenty years. The quantum leap in recent years has established their potential for weight critical application in engineering components and structures in aerospace.

It is shown that the tensile strength is increased with increasing volume fraction of $\mathrm{SiC}$ particulates. This applies to all metal matrix composites including discontinuously reinforce composite reinforced with $\mathrm{SiC}$ particulates or whiskers Figure 2 and 3. The effect of strength may be attributed to the generation of dislocations on cooling of the metal matrix 
composites. Such dislocations have been observes by TEM. A high dislocation density was observed on $\mathrm{Al} 6013 / \mathrm{SiC}$ (p) interface.

In a TEM experiment, the generation of dislocations started only at $500 \mathrm{~K}$ (Vogelsang et al. 1986). It has also been suggested that dislocation were generated in $\mathrm{Al}-6061 / 20 \mathrm{SiC} \mathrm{MMC}$ below $573 \mathrm{~K}$.

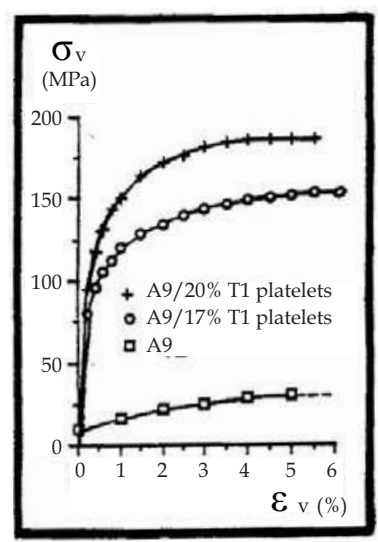

Fig. 2. Effect of the size of the platelets (Massardier et al., 1993)

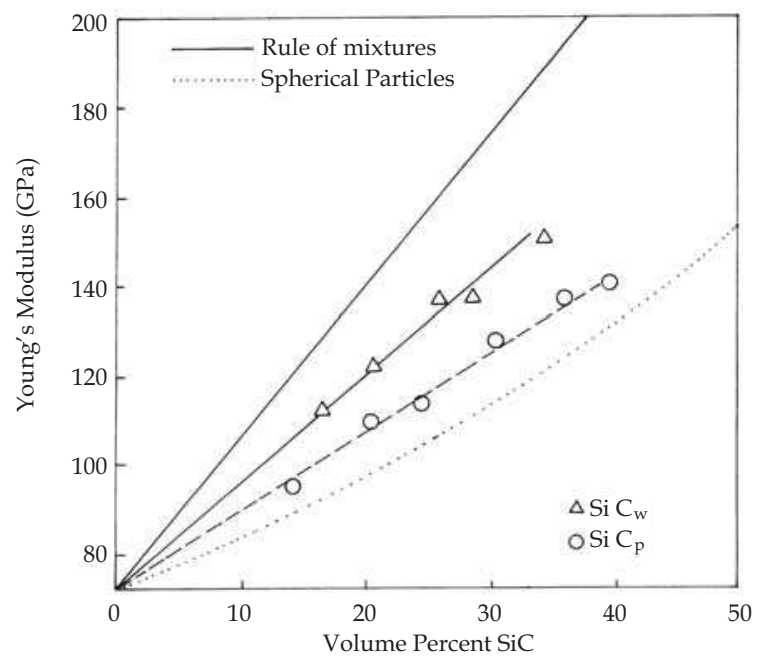

Fig. 3. Young's modulus vs volume percent of $\mathrm{SiCw}$, SiCp and reinforcement (Zaki, 2001)

The elongation (\%) of the MMC decreased with increased particulate contents as shown by $\mathrm{Al} 6061$ / $20 \mathrm{SiC}$ (p) - The mechanism of fracture toughness is not fully understood. The presences of large clusters of particles promote crack propagation whereas their uniform distribution retards crack propagation. The fracture toughness values of selected alloys are given in Table 3. 


\begin{tabular}{|c|c|}
\hline Alloy Designation & Toughness Value \\
\hline $\mathrm{Al} 2009 / \mathrm{SiC} / 15(\%) \mathrm{W}(\mathrm{T} 8)$ & $51 \mathrm{mpa} \sqrt{\mathrm{m}}$ \\
\hline $\mathrm{Al} 6061-40 \% \mathrm{SiC}(\mathrm{p})$ & $122 \mathrm{mpa} \sqrt{\mathrm{m}}$ \\
\hline $\mathrm{Al} 6013-29 \mathrm{SIC}(\mathrm{p})$ & $19.5 \mathrm{KSi} \sqrt{2}$ \\
\hline
\end{tabular}

Table 3. Fracture toughness of selected MMCS

The strains to failure (\%) for different $\mathrm{Al}_{2} \mathrm{O}_{3}$ reinforcement are shown in Table 4 Strain to failure decreases with increase of volume fraction of reinforcement.

\begin{tabular}{|c|c|}
\hline Vf $\%$ & Percent strain to failure \\
\hline & $($ Ef $) \mathrm{mm} / \mathrm{mn}$ *100 \\
\hline $\mathrm{Al} 6061$ & 29.26 \\
\hline $\mathrm{Al} 6061 / 10$ vol. $\% \mathrm{Al} 2 \mathrm{O} 3$ & 4.72 \\
\hline $\mathrm{Al} 6061 / 20$ vol. $\% \mathrm{Al} 2 \mathrm{O} 3$ & 2.29 \\
\hline $\mathrm{Al} 6061 / 30$ vol\% $\mathrm{Al} 2 \mathrm{O} 3$ & 1.42 \\
\hline
\end{tabular}

Table 4. Strain to failure of Alloy Al 6061 with increasing volume fractions (Dehlan and Syed, 2006)

$\mathrm{Al} \mathrm{MMC}$ are finding increasing applications as rotor material in automotive brake systems (Shorowords et al., 2004). Effect of Studies on the effect of sliding velocity on wear friction and tribochemistry of MMC reinforced with $13 \% \mathrm{SiC}$ or $\mathrm{B} 4 \mathrm{C}$ have shown that sliding velocity leads to lower wear rates and lowers friction coefficient for both MMCs.. Studies on interaction between MMC and phenolic brake pads showed that the transfer layer consisting of phenolic pad material acted as a protective layer and reduced wear rates and coefficient of friction. Honda has used aluminum metal matrix cylinder liners in some of their engines including $\mathrm{B} 21 \mathrm{Al}$ and $\mathrm{H} 23 \mathrm{~A}, \mathrm{~F} 20 \mathrm{C}$ and $\mathrm{F} 22 \mathrm{C}$.

The effect of cutting speed on tool wear has been investigated. The cutting tool wear increased with increased reinforcement ratios. At constant speed and feed rate, the lowest wear rate has been found in $5 \mathrm{Wt} \% \mathrm{SiC}(\mathrm{p})$ and the highest wear with $15 \mathrm{Wt} \% \mathrm{SiC}_{\mathrm{p}}$ increased cutting speed increased the tool wear rate.

From the above description, it may be concluded that the development of MMC has been a big breakthrough in search for stiff high strength materials for aerospace and automotive industry particularly. Whereas the mechanical properties of MMC have remained the focus of attention, the work on corrosion behavior of MMC did not proceed hand in hand with the mechanical and tribological properties. The work on corrosion was undertaken the last decade and a considerable progress has been made in the understanding of corrosion behaviour of metal matrix composites in recent years.

\section{Corrosion behavior of Aluminum metal matrix composites}

The corrosion behaviour of alloys in sea water $3.5 \mathrm{Wt} \% \mathrm{NaCl}$ represents an adequate measure of its corrosion resistance. Important results of corrosion studies undertaken in the last decade would be discussed under the following categories. 
a. Immersion and long term exposure tests in sea water or $3.5 \mathrm{wt} \% \mathrm{NaCl}$.

b. Localized corrosion studies

c. Flow induced corrosion and Erosion corrosion

d. Corrosion inhibition

e. Corrosion mechanism

\subsection{Immersion \& long term exposure studies}

The above studies were conducted in accordance with ASTM designation G 31 - 72 (ASTM, 2004). The results of studies on Al6092 - T6, Al/B4C/20P, Al 6092 - T6 /2oSiC(p), and 6092 - T6 20vol\%Al2O3 and monolithic 6061-T6 Al, immersed for 90 days in air exposed 0.5 $\mathrm{Na}_{2} \mathrm{SO}_{4}$ solution, $3.5 \mathrm{wt} \% \mathrm{NaCl}$, ASTM sea water and real sea water were recently described (Hongho et al. 2009). In alloy 6092 - T6 Al/B 4C/20P MMC specimen in ASTM Sea water bubbles were observed. The current over most of the area was found to be anodic. The solution at the anode site was found to be acidic (PH 6.4). Corrosion products were formed as observe after monitoring for three days and the area became more alkaline (PH 8.4). A similar phenomena occurred with alloy 6092 reinforced with $20 \mathrm{Vol}$. \% SiC (p) and gradually the alkalinity increased because of its change of area from and anodic to cathodic. The corrosion rates of MMCS in sea water and ASTM sea water were lower than those in 0.5 $\mathrm{M} \mathrm{Na}_{2} \mathrm{SO}_{4}$ and $3.5 \mathrm{wt} \% \mathrm{NaCl}$. The rates of monolithic 6061 - T6 Al in both real and ASTM sea water were significantly lower than those in $3.5 \mathrm{wt} \% \mathrm{NaCl}$. The surface morphology after the test showed similar general features, one major feature of the surface morphology was the presence of intermetallic precipitates on the surface. The EDS studies suggested these precipitates to contain $\mathrm{Al}, \mathrm{Mg}, \mathrm{O}$, and $\mathrm{C} . \mathrm{Mg}$ and $\mathrm{HCO}_{3}$ irons as the main species corrosion products.

The formation of precipitates is a greater concern in $\mathrm{MMC}$, as localised corrosion is controlled by the formation of such precipitates. The role of precipitates would be discussed in the relevant section of the paper. In general the corrosion rate of Al MMC decreased with time due to the formation of precipitates.

\subsection{Localled corrosion of ALMMC's}

If is generally accepted that MMC are in general more prone to corrosion than their monolithic counterparts (Berkely et al., 1998; Turnbull and Corros, 1992; Trzskoma, 1991). Conflicting views have been presented on the causes of the localised corrosion. The results of the studies showed that galvanic corrosion between the matrix and the reinforcement occurs. However, this is related to the machining conditions. Three different machining process; Wielding Electrical Discharge Machine (WEDM), Cemented Carbide Turning and Single Point Diamond Turning were employed for investigation. The test results for different process are shown in Table 5 (Yue et al., 2002).

\begin{tabular}{|c|c|c|c|c|}
\hline & $E_{\text {Corr }}(\mathrm{mV})$ & $E_{\text {pitl }}(\mathrm{mV})$ & $E_{\text {Pil }}-E_{\text {corr }}(\mathrm{mV})$ & $I_{\text {Corr }}\left(\mathrm{Am}^{-1}\right)$ \\
\hline WED & -761.4 & $-633 \mathrm{v}$ & 128.4 & $3.80 \mathrm{TE}-4$ \\
\hline Carbide Turning & -673.6 & -655 & 186 & $3.194 \mathrm{E}-2$ \\
\hline Diamond Turning & -928.3 & -655 & 288.3 & $1.052 \mathrm{E}-3$ \\
\hline
\end{tabular}

Table 5. Electrochemical parameters for different machining conditions (Yue et al., 2002) 
The electrical discharge machining showed the highest value of pitting potential. The resolidified layer did not show any extensive pitting. The results show that surface conditions have a major effect on pitting potential and the resistance to pitting may be

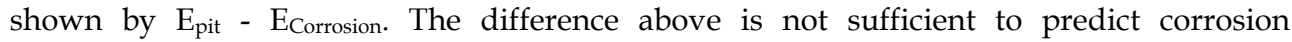
susceptibility. It may be observed that silicon carbide is an insulator and there is hardly any possibility of cathodic reaction occurring on the surface of particles. The theory that $\mathrm{Al} / \mathrm{SiC}$ is sensitive to corrosion because of micro galvanic coupling applies to some intermetallic compounds, cathodic to the matrix such as $\mathrm{CuAl}_{2}$ which is formed. So far there is no general agreement on the role of $\mathrm{SiC}$ particulates on the mechanism of localized corrosion. The electrochemical behaviour of Al2024/AlSiC has been also investigated by scanning micro reference electrode imaging system (Feng et al., 1981; Isacs \& Vyas, 1981). The results of investigations on Al2024/Al SiC (A) are given in Table 6.

\begin{tabular}{|c|c|c|c|c|c|c|c|c|}
\hline $\begin{array}{c}\text { Volume } \\
\text { Fraction }\end{array}$ & \multicolumn{3}{|c|}{$\mathrm{E}_{\text {pitting }}$} & \multicolumn{3}{c|}{$\mathrm{E}_{\text {protection }}$} & \multicolumn{2}{c|}{$\mathrm{E}_{\text {corrosion }}$} \\
\hline & $0.01 \mathrm{~m}$ & $6.1 \mathrm{~m}$ & $0.5 \mathrm{~m}$ & $0.01 \mathrm{~m}$ & $0.1 \mathrm{~m}$ & $0.5 \mathrm{~m}$ & 0.5 & 0.1 \\
& $\mathrm{NaCl}$ & $\mathrm{NaCl}$ & $\mathrm{NaCl}$ & $\mathrm{NaCl}$ & $\mathrm{NaCl}$ & $\mathrm{NaCl}$ & $\mathrm{NaCl}$ & $\mathrm{NaCl}$ \\
\hline 0 & -430 & -497 & -565 & -653 & -620 & -612 & -612 & -574 \\
\hline 5 & -460 & -528 & -597 & -750 & -700 & -670 & -670 & -610 \\
\hline 10 & -485 & -555 & -625 & -740 & $-765115(\mathrm{~T})$ & -720 & -725 & -688 \\
\hline 15 & -538 & -632 & -662 & -700 & -720 & -720 & -750 & -671 \\
\hline 20 & -550 & -650 & -692 & -670 & -670 & -775 & -775 & -671 \\
\hline
\end{tabular}

Table 6. Summary of electrochemical data (Feng et al., 1981; Isacs \& Vyas, 1981)

It was observe that pitting potential $\mathrm{E}_{\mathrm{p}}$ decreased as the volume fraction of $\mathrm{SiC}$ particulate reinforcement increased. The relation between the volume fraction and Eprotection It was clearly observed that the pitting attack occurred at $\mathrm{SiC} / \mathrm{Al}$ interface which contained intermetallic $\mathrm{Cu}$ and $\mathrm{Al}$ precipitates. The presence of $\mathrm{Mg}, \mathrm{Cu}$, and $\mathrm{Fe}$ compounds in $\mathrm{Al6013} / 20 \%$ Vol. of $\mathrm{SiC}$ has been confirmed also in another work in recent years (Zaki et al., 2000). The interfacial regions may act as active centers for localized corrosion on immersion in sodium chloride solution. The EDS spectrum of $\mathrm{Al}_{2} \mathrm{Cu}$ is shown in Figure 4. The pits on $\mathrm{Al}$ 2024/SiC interface are shown in Figure 5. In Al 2024/SiC MMC, Mg may segregate in addition to the precipitates of $\mathrm{Al}_{2} \mathrm{Cu} \mathrm{Mg}$ and $\mathrm{Al}_{2} \mathrm{Cu}$. The segregated magnesium may form active galvanic couple with Al matrix (Jamaludin et al., 2008). There is also the possibility of the intermetallic precipitates to act as local anodes or cathodes because of the difference between the open circuit potentials of these intermetallic with $\mathrm{Al}$ matrix. As seen above the role of the precipitates and inclusion is not clearly understood. However, the evidence of localized corrosion of $\mathrm{Al} \mathrm{MMC} \mathrm{suggests,} \mathrm{that} \mathrm{the} \mathrm{Al} / \mathrm{SiC}$ interface in active and responsible for localized corrosion. This is also confirmed by studies on ( $\mathrm{Al} \mathrm{2009/SiC} \mathrm{W)} \mathrm{(W=} \mathrm{whisker).}$ In the rolled material extensive pitting occurred, and on removing the corrosion products it was observed that the pits contained particles $\mathrm{CuAl}_{2}$ (Rohatgi, 2003). On heat treatment the amount of $\mathrm{CuAl}_{2}$ particles was significantly reduced (Rohatgi, 2003) and the rate of corrosion also diminished which suggested that the heat treatment diminished $\mathrm{Mg}, \mathrm{Fe}$ and $\mathrm{CuAl}_{2}$ precipitates Figure 6 shows the effect of heat treatment on the corrosion behaviour of T6 and as rolled Al 2009/Sic (w) composite. The corroded surface of as rolled specimens is shown in Figure 6. 

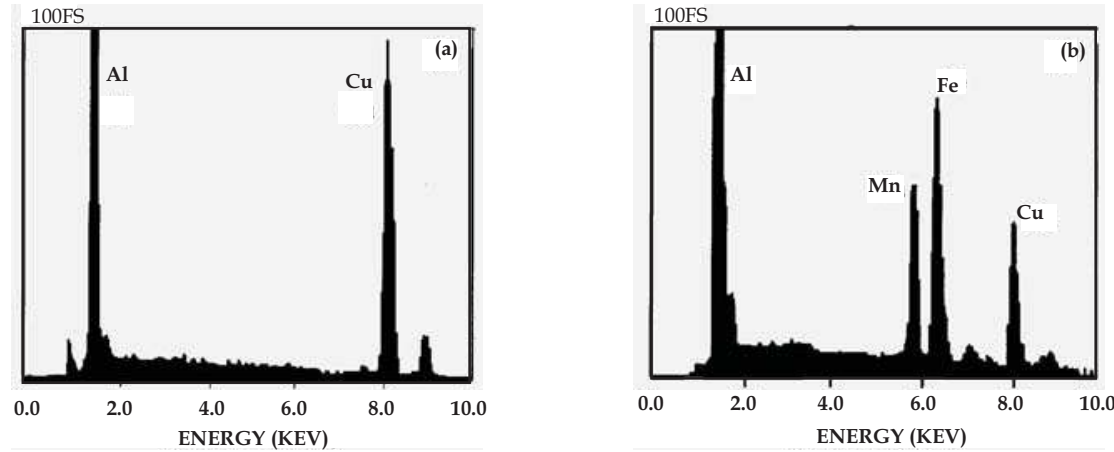

Fig. 4. EDS spectrums of (a) Al2Cu and (b) (CuFeMn) Al6 inclusions (Feng et al., 1998)
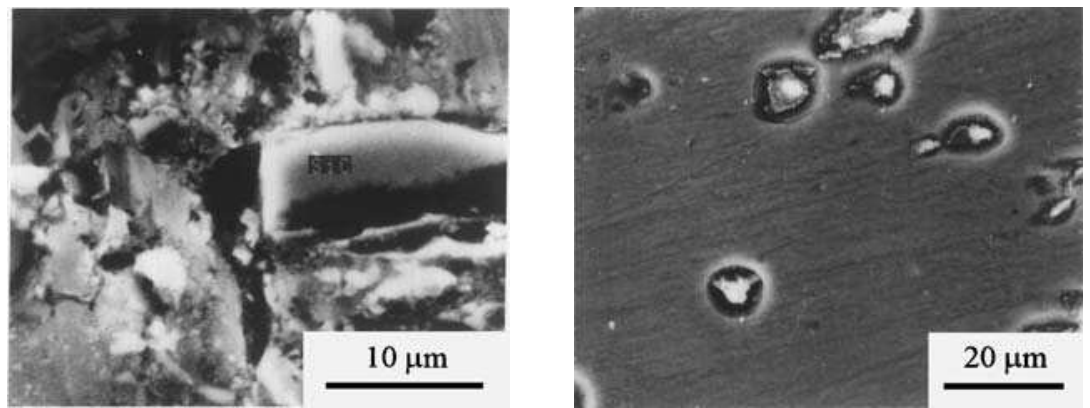

Fig. 5. Scanning electron micrographs of pits on interfaces of (a) SiCp-2024 Al matrix, and (b) inclusions-2024 Al matrix (Feng et al., 1998)

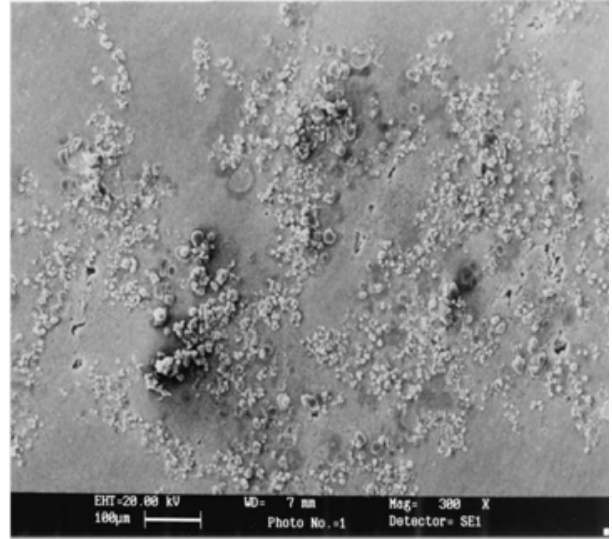

(a)

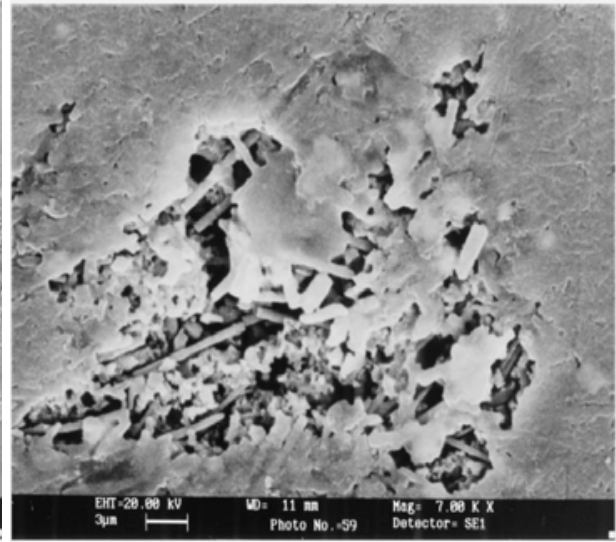

(b)

Fig. 6. Corroded surface of the as-rolled specimen after the polarization test (a), (b) showing pit morphology (Yue et al., 2000) 


\subsection{Flow induced corrosion and Erosion corrosion}

The resistance of metallic equipment and structures to the impact of flow induced corrosion is extremely important as it affects their operational life and integrity of equipment. Whereas the effect of velocity on the erosion/corrosion of steel copper, and aluminium alloys are widely reported in literature the information on the metal matrix composite is scanty (Rohatgi, 2004; Griffen \&Turnbull, 1994; Lin et al., 1992; Mansfield \& Jeanjagnet, 1984; Chen \& Mansfeild, 1997; Hihara, 2010; Colman et al., 2011). Studies on Al 6013-20 SiC were conducted in a customized recirculation loop as shown in Figure 7. It consisted of entry valves, a manometer, a centrifugal water pumps, a flow meter and several specimen holders to accommodate flat specimens. Each specimen holders contained four specimens which were housed in an outside container. The velocity was varied by varying the chamber of the specimen holders. Three tempers of Al6013-20 SiC (p) were investigated in the loop. In which a solution of $3.5 \mathrm{wt} \% \% \mathrm{NaCl}$ was flowing at velocities ranges from $1-4 \mathrm{~ms}^{-1}$.

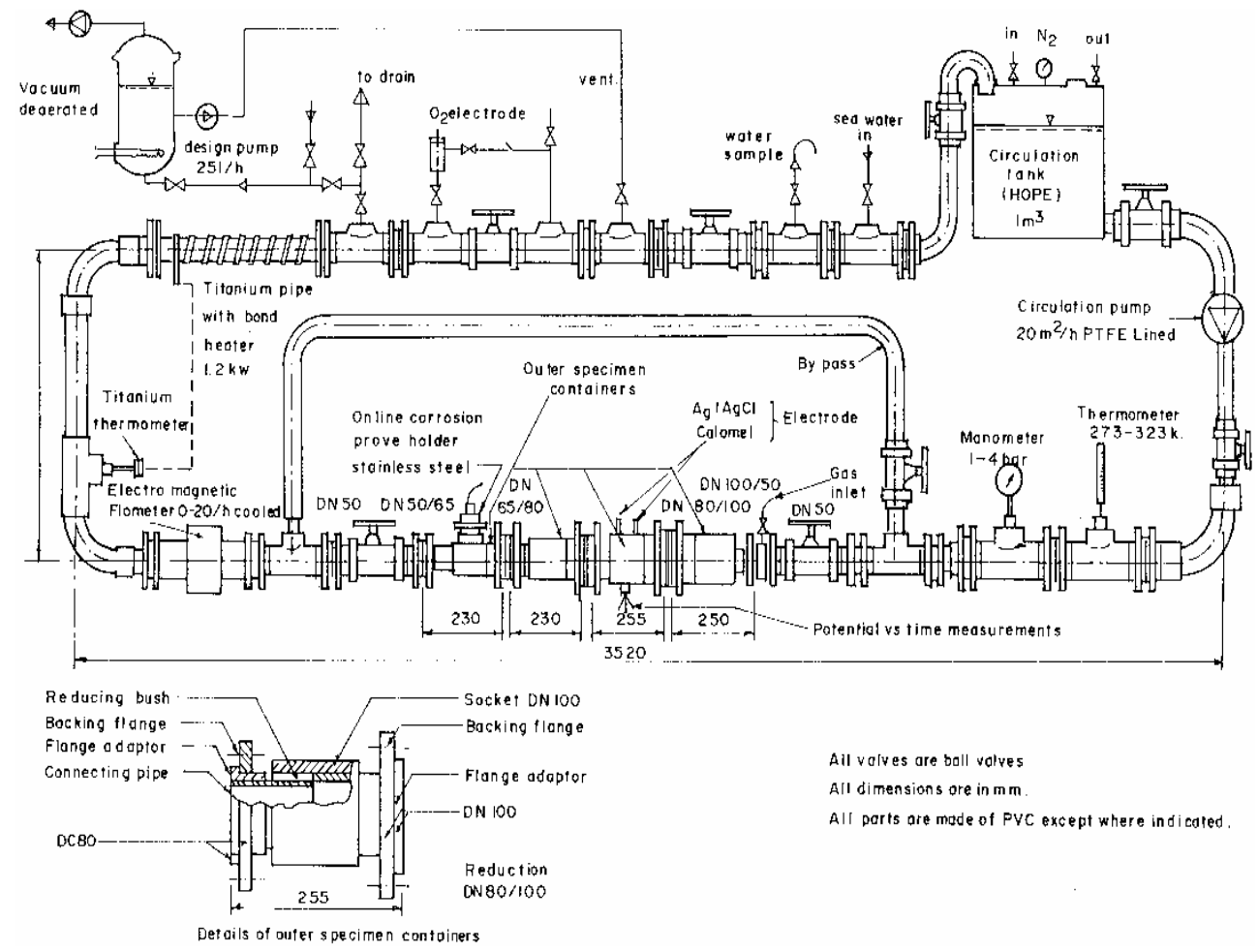

Fig. 7. Schematic diagram of PVC recirculating loop (Zaki, 2001)

After exposure of 100 hours it was shown that temper (0) annealed, and temper $\mathrm{F}$, as fabricated, showed a lower resistance to corrosion in $3.5 \mathrm{wt} \% \mathrm{NaCl}$ with and without polystyrene suspended particles. Upon increasing the temperature form 30 to 50 and $90 \mathrm{C}$, the erosion corrosion rate increased as shown in Table 7 and 8 (Zaki, 2007). 


\begin{tabular}{|c|c|c|c|}
\hline & \multicolumn{3}{|c|}{ Corrosion Rate(In 3 weight\% NaCl + Vol \% Polystyrene $(\mathrm{mpy})$} \\
\hline Velocity & Temper(0) & Temper $(\mathrm{F})$ & Temper T4 \\
\hline 1.0 & 11.8 & 9.9 & 9.6 \\
\hline 2.7 & 12.6 & 10.8 & 10.1 \\
\hline 3.8 & 12.9 & 11.3 & 11.4 \\
\hline
\end{tabular}

Table 7. Variation of Erosion-Corrosion Rate with Velocity in $3.5 \mathrm{wt} \% \% \mathrm{NaCl}+2 \% \mathrm{Vol}$ Polystyrene (Zaki, 2007)

\begin{tabular}{|c|c|c|c|c|}
\hline \multicolumn{2}{|c|}{} & \multicolumn{3}{|c|}{ Erosion Corrosion Rate(mpy) } \\
\hline Temperature $\left({ }^{\circ} \mathrm{C}\right)$ & Velocity & \multirow{2}{*}{ Temper(O) } & Temper(F) & Temper(T4) \\
\hline \multirow{3}{*}{50} & & & 10.3 & 9.9 \\
\cline { 2 - 5 } & 1.0 & 12.1 & 11.2 & 10.1 \\
\cline { 2 - 5 } & 1.9 & 3.6 & 12.1 & 11.4 \\
\cline { 2 - 5 } & 2.7 & 14.2 & 13.6 & 10.3 \\
\cline { 2 - 5 } & 3.8 & 14.9 & 11.9 & 117 \\
\cline { 2 - 5 } & 1.0 & 11.9 & 15.5 & 161 \\
\cline { 2 - 5 } & 1.9 & 15.5 & 17.2 & 148 \\
\cline { 2 - 5 } & 2.7 & 172 & 19.6 & 159 \\
\hline \multirow{4}{*}{90} & 3.8 & 19.6 & 13.3 & 13.3 \\
\cline { 2 - 5 } & 1.0 & 13.3 & 13.1 & 163 \\
\cline { 2 - 5 } & 2.9 & 17.8 & 19.7 & 17.6 \\
\cline { 2 - 5 } & 3.8 & 19.7 & 17.8 & \\
\hline
\end{tabular}

Table 8. The effect of temperature on the erosion - corrosion behavior of $\mathrm{Al} 6013-2051 \mathrm{C}(\mathrm{p})$ in $3.5 \mathrm{wt} \% \mathrm{NaCl}+2 \% \mathrm{Vol}$ Polystyrene (Zaki, 2007)

The erosion-corrosion rate increased, linearly with velocity in the presence of $\mathrm{SiC}$ particles. It was also found that Temper (T4) of the alloy showed the best resistance to corrosion. The rate of erosion corrosion varied also with temperature. The best resistance offered by T4 may be attributed to the homogenization of the surface structure, less clustering of $\mathrm{SiC}$ particles, a uniform distribution of secondary intermetallic phases such as $\mathrm{CuAl}_{2}$ and minimization of micro-crevices (Zaki, 2000). The localized attack was confined to Al 6013/20 SiC (p) interface. A large number of secondary phase particles were observed. After studies showed the presence of $\mathrm{Cu} 3.55 \%$, Fe $1.77 \%, \mathrm{Mg} 1.71 \%$, and some $\mathrm{Cl}(0.32 \%)$ a high dislocation density was observed at the interface Figure 8 (Zaki, 2000). The formation of coherent films was made more difficult by the protrusion of the particles. This factor adds significantly the erosion -corrosion caused by polystyrene particles. The surface is subjected to a cycle of destruction and reformation of a protective film as a result of impact of polystyrene particles. The corrosion product which accumulates at the interface may act as cathode and increase the cathode / anode area ratio causing an overall increase in the rate of corrosion. Alloy $\mathrm{Al} 6013$ / $20 \mathrm{SiC}$ (p) in temper T4 offered of temper T4 offered a good resistance to erosion-corrosion. It can be used in water containing Silica or other particulate matter without undertaking any major risk. Al 6013 reinforced with $20 \mathrm{Vol}$ \% SiC (p) was designed to have improved mechanical properties over those of AAl11 6061/SiC (p). The corrosion resistance of al 6013 /20 Sic (p) was determined in fog testing cabinet (Zaki, 2000). A 
schematic of salt spray chamber is given in Figure 9. The cabinet comprised of a basic chamber level matic test reservoir (1.0 gal salt solution), reservoir (3.0 gal), bubble tank, twin optic fog assembly, and accessories such as a lower assembly bubble tank heater, control valves, and cabinet heaters. The cross section of the assembly is shown in Figure 10. The results obtained for $\mathrm{O}, \mathrm{F}$, and $\mathrm{T} 4$ Tempers of the alloy composite in the fog cabinet are shown in Table 9.

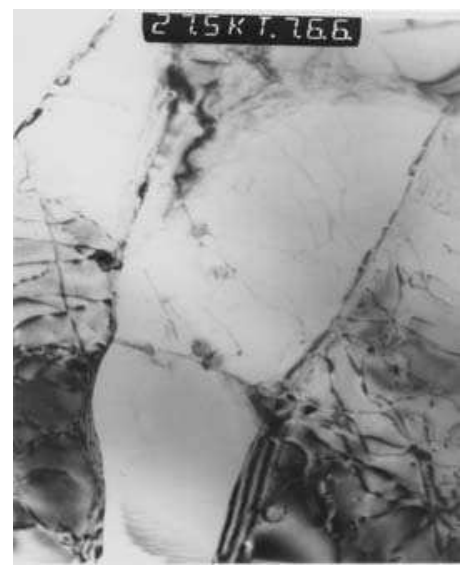

Fig. 8. TEM micrograph of $\mathrm{Al} 6013 / \mathrm{SiC}$ interface showing dislocation generations

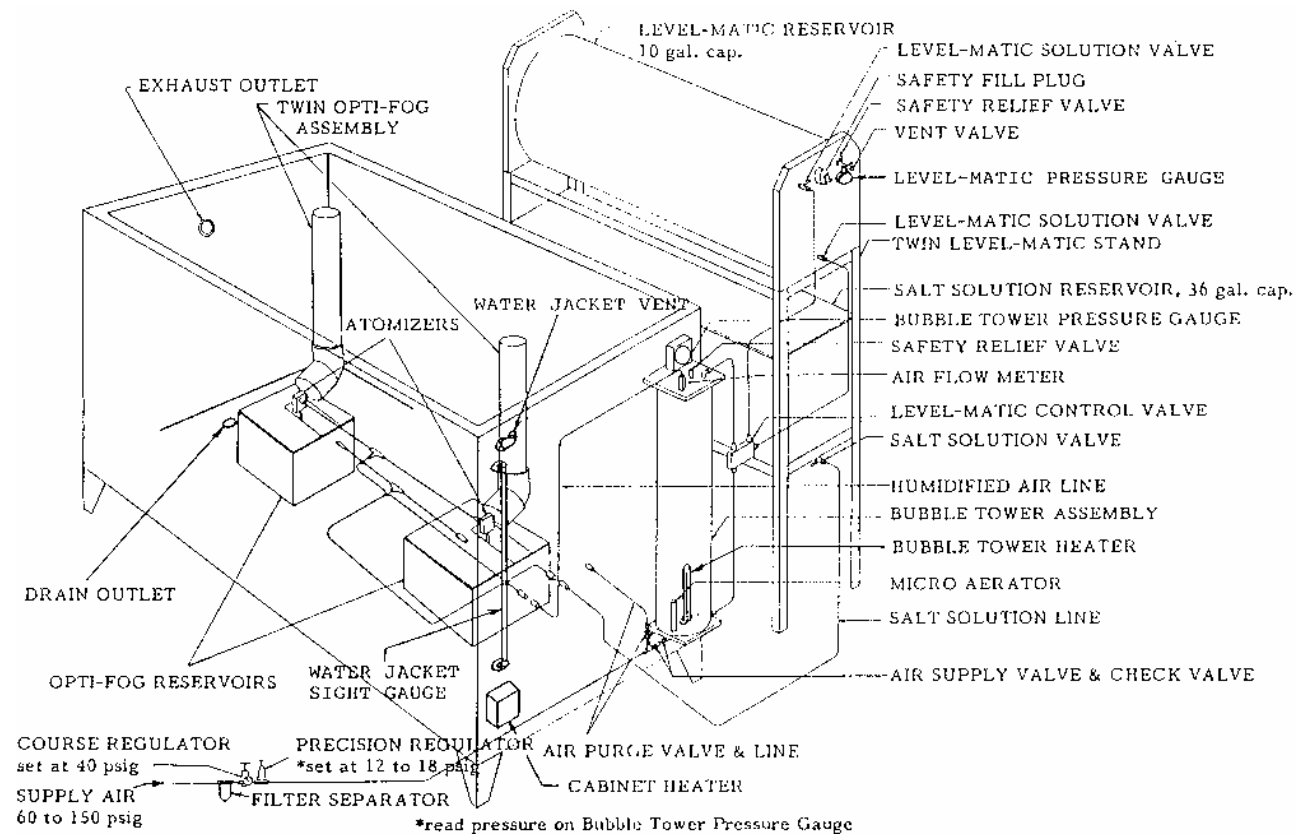

Fig. 9. A schematic of salt spray chamber 


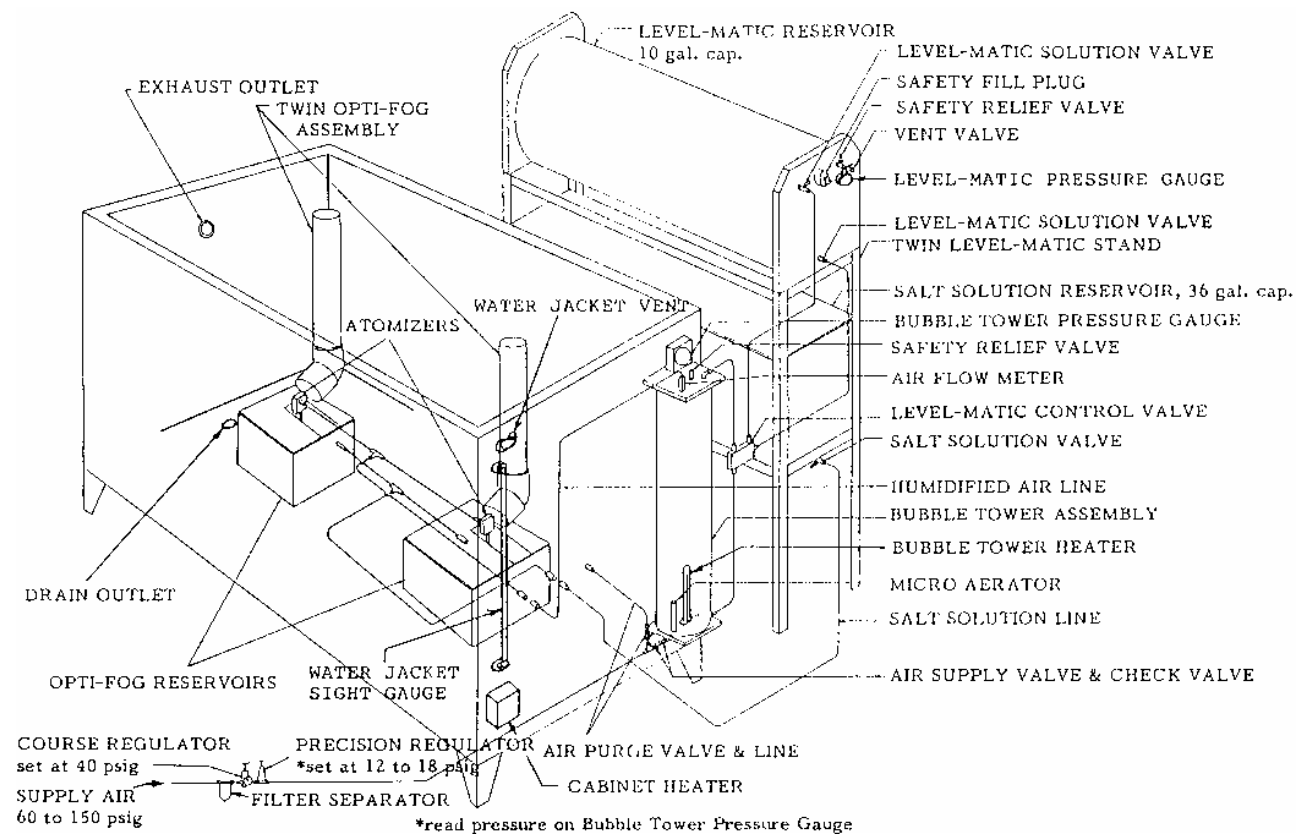

Fig. 10. Cross section of singleton salt fog corrosion test cabinet

\begin{tabular}{|c|c|c|c|}
\hline Time & Temper-0 & Temper-F & Temper-T4 \\
\hline 200 & $10.23 \mathrm{~V}(19.8)$ & $8.42(15.78)$ & $7.12(13.35)$ \\
\hline 400 & $9.11(17.8)$ & $7.78(14.58)$ & $6.18(11.09)$ \\
\hline 600 & $6.38(11.96)$ & $6.06(9.49)$ & $4.38(8.21)$ \\
\hline 800 & $21.92(9.23)$ & $3.98(7.46)$ & $2.82(5.28)$ \\
\hline 1000 & $4.66(8.74)$ & $3.76(7.05)$ & $2.63(4.53)$ \\
\hline 1200 & $4.27(8.01)$ & $3.68(6.90)$ & $2.50(4.83)$ \\
\hline
\end{tabular}

Table 9. Corrosion rates of $\mathrm{Al} 6013 / 20 \mathrm{SiC}(\mathrm{p})$ in Salt Spray Chamber

A decrease in corrosion rate with increased exposure period was observed for all three tempers. The MMC temper T4 showed the highest resistance to pitting. The surface of the composite was often covered with a gelatinous product of aluminum hydroxide $\mathrm{Al}(\mathrm{OH})_{3}$. The pit environment was acidic and bubbles of hydrogen rose from the surface forming corrosion chimneys. The hydrogen bubbles pump up $\mathrm{AlCl}_{3}(\mathrm{OH})_{3}$ to the outside which reacts with water to form $\mathrm{Al}(\mathrm{OH})_{3}$ (Burleigh et al., 1995). The pitting depth in temper $\mathrm{T} 4$ were lower than pitting depths in $\mathrm{F}$ and $\mathrm{O}$ tempers. It was reported that a high concentration of intermetallic compounds was observed at $\mathrm{Al} / \mathrm{SiC}$ inter-phases which lead to localized corrosion (A). The corrosion rate of Al6013-20SiC (p) decreased for all tempers on increasing the temperature form 50 to $75^{\circ} \mathrm{C}$ and increased again on raising the temperature to $100^{\circ} \mathrm{C}$. This change may be attributed to the changes brought about by the composition of the protective films from being bayerite $(\mathrm{AlO}(\mathrm{OH}))$ to boehmite $\left(\mathrm{Al}_{2} \mathrm{O}_{3}, \mathrm{H}_{2}\right)$ as shown by FTIR (Fourier transformation infra-red) spectroscopy). 
The corrosion behavior of Al6013-20SiC (p) is a very strong function of $\mathrm{Al}(\mathrm{OH}) 3$ and once the film formation is completed it becomes independent of oxygen (Beccario et al., 1994). The crystals of boehmite have been observed on the surface of the alloy. The data generated in highly aggressive environment shows promising applications potential of this alloy in salt water and humid environment typical of sea coastal environment in the Gulf Region.

\subsection{Effect of Inhibitors}

It has been shown in earlier sections that $\mathrm{Al} / \mathrm{SiC}$ metal matrix composites such as $\mathrm{Al}$ 6013-20 $\mathrm{SiC}(\mathrm{p})$ exhibit improved mechanical and physical properties compared to wrought alloys. However, they are more susceptible to pitting than their monolithic counterparts (Beccario et al., 1994; Trazaskama, 1990). They also exhibit a higher corrosion rate at velocities greater than the $2.3 \mathrm{~ms}^{-1}$ (Zaki, 2000). A variety of surface modification techniques such as anodizing, chromate conversion coatings and organic finishing have been suggested for the protection of aluminum metal matrix composite from localized corrosion (Aylor \& Moran, 1986; Lin et al., 1989; Mansfield et al., 1990). Cerium coatings have been the focus of attention in the last decade (Hinton \& Arnold, 1986; Davenport et al., 1991).

Studies on to investigate the effect of inhibitors on $\mathrm{Al} 6013-20 \mathrm{SiC}$ (p) included weight loss, Electrochemical and re-circulation loop studies (Zaki, 2009).

Following inhibits solutions were used

a. $1000 \mathrm{ppm} \mathrm{K}_{2} \mathrm{Cr}_{2} \mathrm{O}_{7}+1000 \mathrm{pm} \mathrm{NaHCO}+3.5 \mathrm{wt} \% \mathrm{NaCl}$

b. $\quad 1000 \mathrm{ppm}$ Cerium chloride $+3.5 \mathrm{wt} \% \mathrm{NaCl}$

c. $1000 \mathrm{ppm}$ sodium molybdate $+3.5 \mathrm{wt} \% \mathrm{NaCl}$

The results of inhibitive action of $\mathrm{K}_{2} \mathrm{Cr}_{2} \mathrm{O}_{7}+1000 \mathrm{pm}$ NaHCO3 are summarized in Table 10 .

\begin{tabular}{|c|c|c|c|}
\hline $\begin{array}{c}\text { Alloy } \\
\text { Designation }\end{array}$ & $\begin{array}{c}\text { Velocity } \\
(\mathrm{ms}-1)\end{array}$ & $\begin{array}{c}\text { Corrosion rate in mpy(MDD) } \\
\text { with no inhibitor }\end{array}$ & $\begin{array}{c}\text { Corrosion rate in } \\
\text { mpy(MDD)with } \\
\text { inhibitors }\end{array}$ \\
\hline \multirow{3}{*}{$\begin{array}{c}\mathrm{Al} 6013-20 \\
\mathrm{SiC}(\mathrm{p})-\mathrm{O}\end{array}$} & 1.0 & $11.8(22.1)$ & $3.07(5.76)$ \\
\cline { 2 - 4 } & 1.9 & $11.6(21.7)$ & $7.63(14.32)$ \\
\cline { 2 - 4 } & 2.7 & $12.9(24.1)$ & $8.4(15.77)$ \\
\cline { 2 - 4 } & 1.8 & $13.6(25.5)$ & $9.63(18.08)$ \\
\hline \multirow{3}{*}{$\begin{array}{c}\mathrm{Al} 6013-20 \\
\mathrm{SiC}(\mathrm{p})-\mathrm{F}\end{array}$} & 1.9 & $9.9(18.5)$ & $3.61(5.68)$ \\
\cline { 2 - 4 } & 2.7 & $10.4(19.5)$ & $4.31(8.09)$ \\
\cline { 2 - 4 } & 3.8 & $10.8(20.2)$ & $5.53(10.38)$ \\
\hline \multirow{2}{*}{$\begin{array}{c}\mathrm{Al} 6013-20 \\
\mathrm{SiC}(\mathrm{p})-\mathrm{T} 4\end{array}$} & 1.0 & $11.3(21.2)$ & $6.60(12.39)$ \\
\cline { 2 - 4 } & 1.9 & $9.6(18.5)$ & $2.01(3.77)$ \\
\cline { 2 - 4 } & 2.7 & $10.1(18.2)$ & $3.70(5.07)$ \\
\cline { 2 - 4 } & 3.8 & $10.8(20.2)$ & $3.80(7.13)$ \\
\hline
\end{tabular}

Note; All experiments were conducted in $3.5 \mathrm{wt} \% \mathrm{NaCl}$

Table 10. The results of inhibitor action of k2Cr2O7+1000 ppm NaHCO3 (Zaki, 2009) 
The reduction in the corrosion rate with $\mathrm{K}_{2} \mathrm{Cr}_{2} \mathrm{O}_{7}+\mathrm{NaHCO}_{3}$ has been attributed to the formation of protective layer of boehmite $\mathrm{Al}(\mathrm{OH})_{3}, 3 \mathrm{H}_{2} \mathrm{O}$ and bayrite $\mathrm{Al}_{2} \mathrm{O}_{3}, \mathrm{H}_{2} \mathrm{O}$. The breakdown of the oxide layer leads to pitting. The reduction in the corrosion resistance at increased velocities is caused by continuous removal of protective layer by erodent particles. The protrusion of particulates also makes it difficult to achieve a passivating layer; hence the resistance to the impact of velocity is lowered.

The preferred site for localized corrosion is $\mathrm{Al} / \mathrm{SiC}$ interface as this site is abundant in intermetallic compound (Zaki, 1998). The existence of thermal stresses and dislocation density at interface affects the kinetics of erosion corrosion and increases the sensitivity if $\mathrm{Al} / \mathrm{SiC}$ interfaces to erosion-corrosion. Because of the encouraging results of inhibition treatment of Al7057, and Al1000, with cerium chloride and sodium molybdate, studies were further conducted on Al6013 -20 Vol. \% SiC(p) MMC. The effect of inhibition treatment is shown in Table 11 below.

\begin{tabular}{|c|c|c|c|c|}
\hline \multirow[b]{2}{*}{ Sr. No } & \multirow[b]{2}{*}{ Temperature ${ }^{\circ} \mathrm{C}$} & \multicolumn{2}{|c|}{$\begin{array}{l}\text { Corrosion rate in 3.5\% } \\
\mathrm{NaCl}+1000 \mathrm{ppm}\end{array}$} & \multirow{2}{*}{$\begin{array}{c}\text { Corrosion rate in } \\
3.5 \% \mathrm{NaCl}+1000 \mathrm{ppm} \\
\mathrm{Namoo} 4, \mathrm{CeCl} 3 \\
\mathrm{Mpy}(\mathrm{mdd})\end{array}$} \\
\hline & & Temper & $\operatorname{Mpy}(\mathrm{mdd})$ & \\
\hline \multirow{3}{*}{1} & \multirow{3}{*}{50} & 0 & $4.72(8.86)$ & $3.8(7.13)$ \\
\hline & & $\mathrm{F}$ & $2.24(4.13)$ & $1.8(3.38)$ \\
\hline & & $\mathrm{T} 4$ & $1.71(3.21)$ & $0.9(1.69)$ \\
\hline \multirow{3}{*}{2} & \multirow{3}{*}{70} & 0 & $8.3(15.5)$ & $5.06(9.5)$ \\
\hline & & $\mathrm{F}$ & $6.53(12.26)$ & $4.01(7.5)$ \\
\hline & & $\mathrm{T} 4$ & $2.54(4.77)$ & $2.01(3.72)$ \\
\hline \multirow{3}{*}{3} & \multirow{3}{*}{100} & 0 & $12.90(24.2)$ & $8.05(15.11)$ \\
\hline & & F & $11.60(21.7)$ & $8.26(15.41)$ \\
\hline & & $\mathrm{T} 4$ & $10.19(19.13)$ & $5.41(10.15)$ \\
\hline
\end{tabular}

Table 11. Effect of Inhabition Treatment

As shown by table 11 cerium chloride is a more effective inhibitor than sodium molybdate as shown by a larger reduction in corrosion rate brought about by addition of cerium chloride compared to sodium molybdate. The corrosion rate of temper of the MMC is reduced from 19.13 mpy to 3.96 with Cerium Chloride at $100^{\circ} \mathrm{C}$ which is very significant. Electrochemical studies were also conducted at 50,70 and $100^{\circ} \mathrm{C}$ to observe the effect of temperature on inhibition. The electrochemical data obtained by above studies is shown Table 12.

The results of studies summarized in Table 12 clearly established that cerium chloride is a more affective inhibitor than sodium molybdate. The large difference between the corrosion potential $\left(\mathrm{E}_{\text {corr }}\right)$ and the pitting potential $\left(\mathrm{E}_{\mathrm{p}}\right)$ shows that the cerium chloride is a more affective inhibitor in $3.5 \mathrm{wt} \% \mathrm{NaCl}$. The corrosion potential $\left(\mathrm{E}_{\mathrm{corr}}\right)$ shifts closer to $\mathrm{E}_{\mathrm{p}}$ which shows the sensitivity of the MMCS to localized pitting in Sodium Chloride without inhibition. The cathodic polarization curve of temper T4 of the alloy in $3.5 \mathrm{wt} \% \mathrm{NaCl}+1000$ ppm $\mathrm{CeCl}_{3}$ in dearated condition is shown Figure 11. The curves are overlaid on the main curve. A maximum reduction in current density (from 234 to $25.1 \mathrm{uA} / \mathrm{cm} 2$ ) is exhibited by Temper T4 in cerium chloride (Zaki, 2009). The current densities recorded are summarized in the Table 13. 


\begin{tabular}{|c|c|c|c|c|c|c|}
\hline Solution & $\begin{array}{c}\text { Temperature } \\
{ }^{\circ} \mathrm{C}\end{array}$ & Temper & R(K.ohms) & $\mathrm{E}_{\text {corr }}(\mathrm{mv})$ & $\mathrm{I}_{\text {corr }}\left(\mu \mathrm{A} / \mathrm{cm}^{2}\right.$ & $\begin{array}{l}\text { Corrosion } \\
\text { rate } \\
\text { mpy (mdd) }\end{array}$ \\
\hline \multirow{3}{*}{$\begin{array}{l}\text { Cerium } \\
\text { Chloride }\end{array}$} & 50 & $\mathrm{O}$ & 9.004 & -0.8 & 3.727 & $1.60(2.99)$ \\
\hline & 50 & F & 3.301 & -0.783 & 0.57 & $2.80(5.28)$ \\
\hline & 50 & T.4 & 2.43 & -0.78 & 1.1 & $0.47(0.88)$ \\
\hline \multirow{3}{*}{$\begin{array}{l}\text { Cerium } \\
\text { Chloride }\end{array}$} & 70 & $\mathrm{O}$ & 1.281 & -0.909 & 4.757 & $2.04(3.81)$ \\
\hline & 70 & $\mathrm{~F}$ & 9.14 & -0.915 & 3.993 & $1.68(3.14)$ \\
\hline & 70 & T.4 & 10.07 & -0.993 & 2.155 & $0.92(1.71)$ \\
\hline \multirow{6}{*}{$\begin{array}{l}\text { Sodium } \\
\text { Molybdate }\end{array}$} & 50 & $\mathrm{O}$ & 44.5 & -0.8 & 150 & $1.24(3.22)$ \\
\hline & 50 & $\mathrm{~F}$ & 11.91 & -0.716 & 216.5 & $1.92(3.60)$ \\
\hline & 50 & T.4 & 41.3 & -0.791 & 72.8 & $0.47(0.88)$ \\
\hline & 70 & $\mathrm{O}$ & 58.77 & -0.909 & 272.6 & $2.74(5.11)$ \\
\hline & 70 & $\mathrm{~F}$ & 23.76 & -0.916 & 137.0 & $2.12(4.06)$ \\
\hline & 70 & T.4 & 34.87 & -0.867 & 111.5 & $0.75(1.46)$ \\
\hline \multirow{3}{*}{$\begin{array}{l}\text { Sodium } \\
\text { Molybdate }\end{array}$} & 100 & $\mathrm{O}$ & 100 & -0.87 & 100 & $8.60(16.00)$ \\
\hline & 100 & $F$ & 100 & -0.868 & 100 & $6.50(12.16)$ \\
\hline & 100 & T.4 & 58 & -0.947 & 74 & $3.96(7.41)$ \\
\hline
\end{tabular}

Table 12.

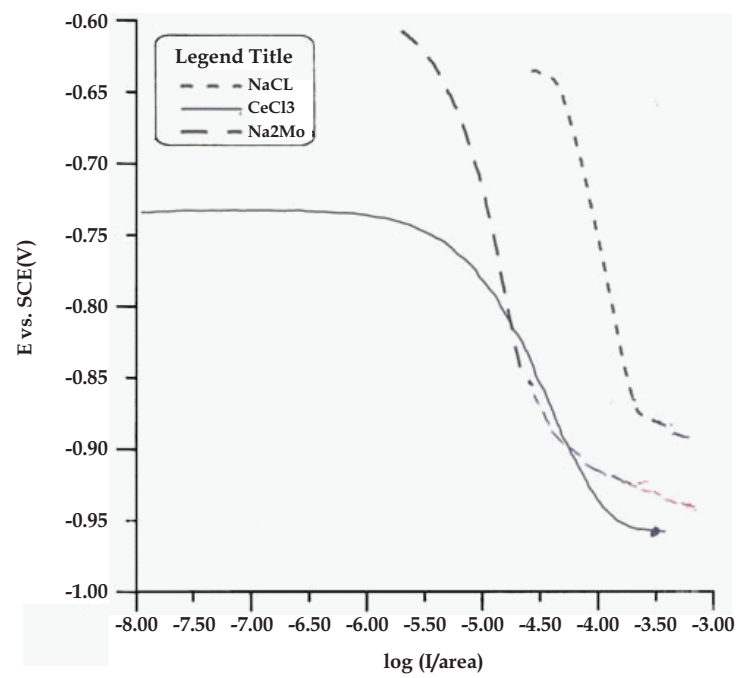

Fig. 11. A cathodic polarization curve of temper T4 of the alloy in $3.5 \mathrm{wt} \% \mathrm{NaCl}+1000 \mathrm{ppm}$ $\mathrm{CeCl}_{3}$ in deaerated condition (Zaki, 2009)

\begin{tabular}{|c|c|c|}
\hline Sr. No. & Media & $\operatorname{Icorr}(\mu \mathrm{A} / \mathrm{cm} 2)$ \\
\hline 1 & $3.5 \mathrm{wt} \% \mathrm{NaCl}$ & 234 \\
\hline 2 & $3.5 \mathrm{wt} \% \mathrm{NaCl}+1000 \mathrm{ppm} \mathrm{Cecl3}$ & 25.1 \\
\hline 3 & $3.5 \mathrm{wt} \% \mathrm{NaCl}+1000 \mathrm{ppm} \mathrm{NaMoo} 4$ & 178 \\
\hline
\end{tabular}

Table 13. Current Densities of MMCS after Inhibition (Zaki, 2009) 
Cerium chloride acts as a strong cathodic inhibitor for the alloy. Sodium molybdate on the other hand acts as an anodic inhibitor which acts by raising the pitting potential (Up) in the positive direction while maintaining $\mathrm{E}_{\mathrm{corr}}$ negative to $\mathrm{E}_{\mathrm{p}}$. A typical cyclic polarization curve of the temper T4 of the alloy in $3.5 \mathrm{wt} \% \mathrm{NaCl}+1000 \mathrm{ppm} \mathrm{NaMoO}_{4}$ is shown in Figure12. The corrosion potential tends to shifts to more positive values.

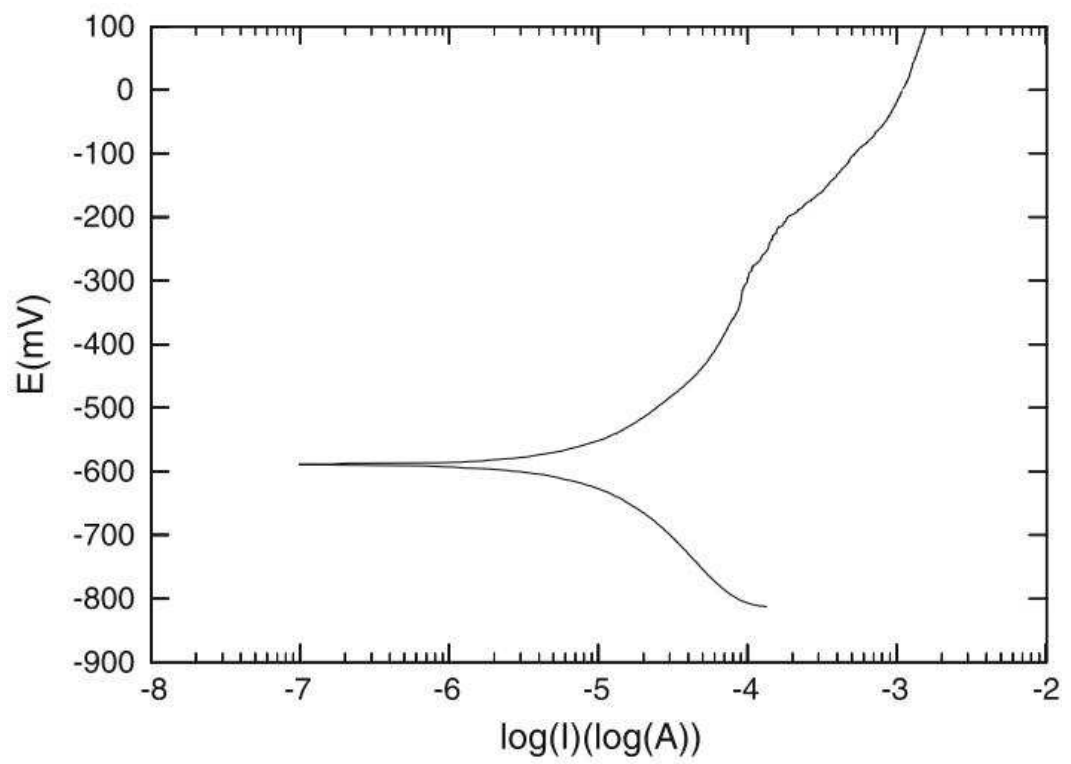

Fig. 12. A typical cyclic polarization curve of $\mathrm{Al} 6013-20 \mathrm{SiC}(\mathrm{p})-\mathrm{T} 4$ temper of the alloy in 3.5 wt. $\% \mathrm{NaCl}+1000 \mathrm{ppm}$ sodium molybdate in deaerated conditions

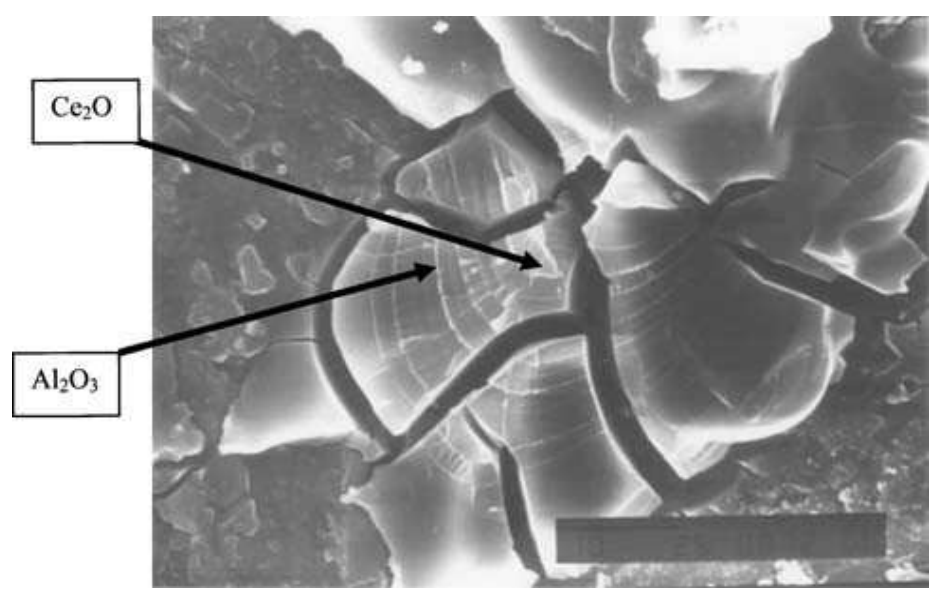

Fig. 13. Surface morphology of $\mathrm{Al} 6013-\mathrm{SiC}$ (p) in 3.5 wt. \% $\mathrm{NaCl}$ containing 1000 ppm CeCl3 (Zaki, 2009) 
It is interesting to relate the surface morphology to localized corrosion. Typical features of surface morphology after inhibitor treatment are shown in figure 13. Deposition of two types of the particles in concentric rings is seen. These are particles of $\mathrm{Ce}_{2} \mathrm{O}_{3}$ and $\mathrm{Al}_{2} \mathrm{O}_{3}$. The square shaped particles of cerium oxide are shown in Figure 14. The oxide layer comprising of $\mathrm{Ce}_{2} \mathrm{O}_{3}$ and $\mathrm{Al}_{2} \mathrm{O}_{3}$ are very stable and protect the $\mathrm{MMC}$ from corrosion in $3.5 \mathrm{wt} \% \mathrm{NaCl}$. However, once the layer reaches a certain thickness, it flakes off. The broken oxide layer in

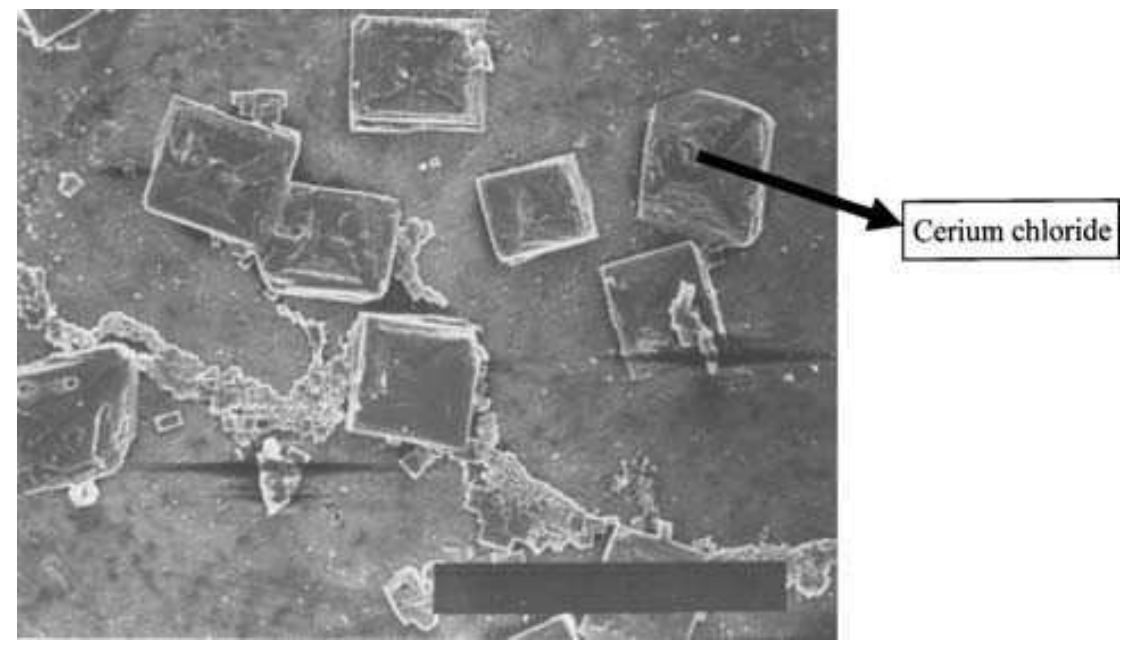

Fig. 14. Square-shaped particles containing predominantly cerium chloride formed on cathodic polarization (Zaki, 2009)

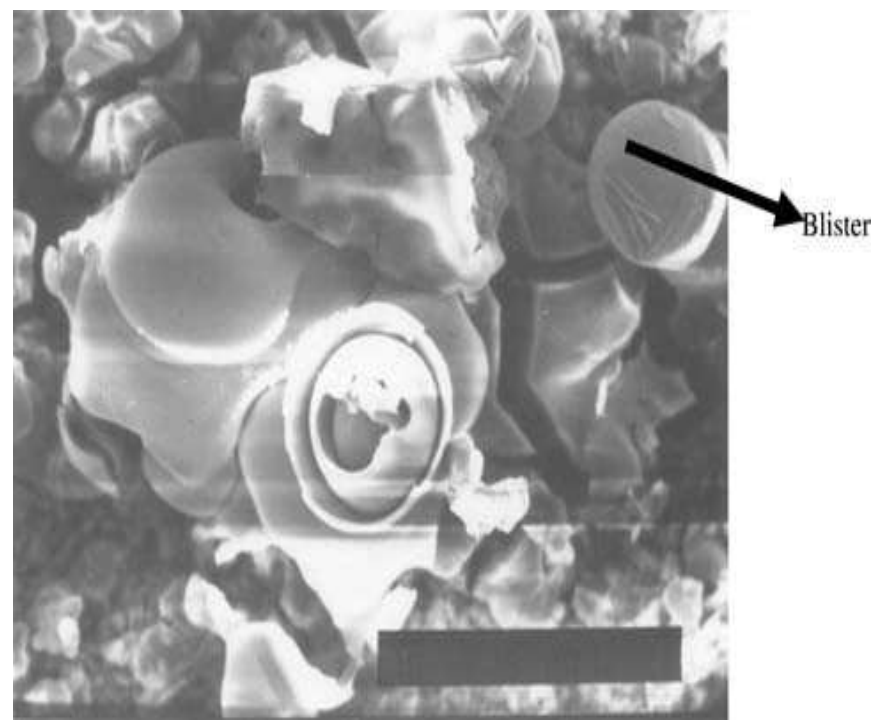

Fig. 15. Broken oxide layer forming blisters (mothballs) 
the form of mothballs can be observed in Figure 15. It has been reported that cathodic reaction proceeds at the sites of intermetallic precipitates of copper and its solution becomes alkaline. The film of cerium oxide replaces the film of aluminum hydroxide with increased exposure time (Muhammad \& Edwin, 2004; Misra et al., 2007). Whereas the studies on the inhibition of AlMMC are still lacking, there is sufficient evidence to show that cerium chloride is an effective inhibitor for corrosion protection of AlMMC Sodium molybdate is not as effective as cerium chloride shown by the studies reported above composite in chloride containing environment.

\subsection{Corrosion mechanism}

Despite decades of research no conclusive mechanism on the localized corrosion of $\mathrm{Al} / \mathrm{SiC}(\mathrm{p})$ composites has been described - The role of intermetallic and dislocation generation at $\mathrm{Al} / \mathrm{Sic}(\mathrm{p})$ interface has not been conclusively established. No attack a SiC particles has been reported in literature.

From several reliable studies it may be concluded that the pitting potential of monolithic alloys depends on the alloy composition and Ep which is more positive than that of reinforced material (Monticelli et al., 1997; Trazaskoma et al., 1990). The pitting resistance of several MMC investigated followed the order, Al2024 = Al6013 - 20Sic (p) > AL 6061>, Al 6013-20SiC (p) T4=Al5456 (Zaki 2000). In the studies conducted an abundant distribution of copper and secondary phase particles of $\mathrm{Mg}$ and Fe were observed.

Copper particles were also present in pit cavities. Analysis of corroded regions at the interface showed a greater concentration of copper compared to the surface away from the interface. The presence of $\mathrm{AlCl}_{3}$ in the oxide film has been indicated by EDS studies (Trazaskoma et al., 1990). Results show a high concentration of copper (3.5\%) and $\mathrm{Fe}$ $(1.77 \%)$. There is therefore, a sufficient evidence to show that the increased reactivity at the interface is responsible for localized corrosion of composites. The intermetallic precipitates act as anodic or cathodic sites for initiation of localized corrosion. It is also observed that homogenization of the surface minimizes corrosion the reactivity at the interface is further minimized as shown by temper T4. The SiC particles do not provide any sites for initiation of pits. A higher concentration of copper in pit cavities may be attributed to higher velocities which transport copper ions. Dislocation generation at the interface further activates the interface.

Two more factors are reported to influence, the mechanism of corrosion; Na:YAG laser treatment and machining. Electrochemical studies undertaken showed that the corrosion potential $\left(E_{\text {corr }}\right)$ increased by $79 \mathrm{mv}$ and the corrosion current density decreased by an order of magnitude for the laser treated specimens whereas the untreated surface showed extensive corrosion accompanied by abundant pits. The decrease of corrosion is reported to be due to reduction in the concentration of intermetallic precipitates.

The effect different machining conditions, WEDM, Carbide Turning and Diamond Turning on the electrochemical corrosion behaviour are shown in Figure 16. No significant difference in pitting corrosion potential between the three machining condition was observed. The magnitude of corrosion current for the three machining conditions however differed. Diamond turned specimens showed shallow pits at isolated sites accompanied by a high corrosion rate, whereas Carbide Turned specimens showed extensive pitting because of the hindrance of repassivation of pits due to micro and large crevices present on the surface, pits developed were deeper. 


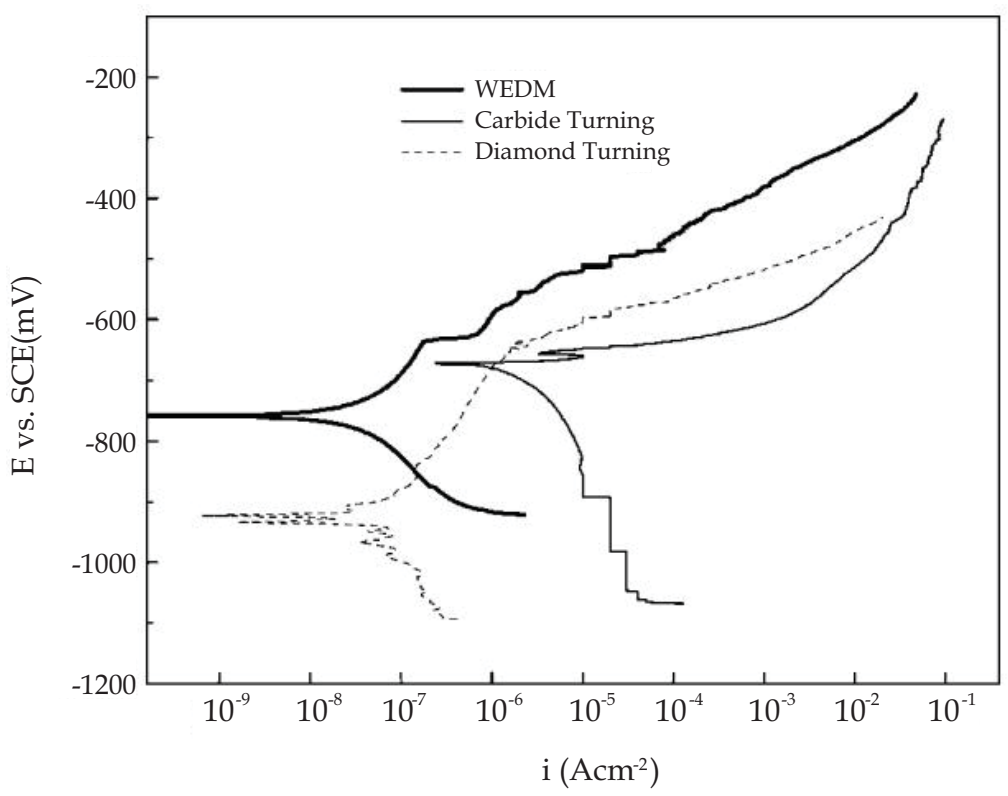

Fig. 16. Potentiodynamic polarization curves of the composite machined to different conditions (Yue et al., 2002)

In the eclectically discharged machined specimen, a resolidified layer of aluminium provided a blanketing effect on the substrate. A reasonable range of passivity was produces on the surface. The high resistance was provided by a layer of oxide on the resolidified aluminium layer created by machining. From the above evidence it is to be understood that surface morphology plays an important role at the $\mathrm{Al} / \mathrm{SiC}$ interface. Scanning micro reference studies has been employed for direct mapping the active centers on surface of electrode with a low dimensional resolution in micrometers. Evidence of micro pitting has been observed at the open-circuit potentials which were more negative than the pitting potential. In their studies, the same conclusion was reached; i. e the $\mathrm{SiC} / \mathrm{Al}$ interface is the active center for localized corrosion due to the precipitation of intermetallic compounds (Zaki, 2000).

The observation that heat treatment increases corrosion resistance is shown by temper T4 of Al6013 / $20 \mathrm{SiC}$ (p), it is further supported by studies on temper T6 of Al2009/SiC (w), which showed a higher resistance to pitting compared to as rolled specimens It has been already stated above their heat treatment induces homogenization which causes a reduction in the concentration of intermetallic compounds and hence, reduces localized Corrosion.

From the above discussion it may be concluded that the composites are more sensitive to pitting than their monolithic counterparts unless they are subjected to T4 or T6 heat treatment. These is sufficient evidence to show $\mathrm{AL} / \mathrm{SiC}$ interface is the main target of localized corrosion due to the presence of intermetallic particulates and inclusion which may form micro-galvanic cells and induce localized corrosion. It is also observed that $\mathrm{SiC}$ particles are not attacked. 
Surface treatment has a significant effect are localized corrosion as shown by the effect of laser treatment and effect of machining on the surface. The scanning micro effloresce electrode studies have shown that $\mathrm{Sic} / \mathrm{Al}$ interface is the centre $\mathrm{f}$ localized corrosion.

Although no conclusion mechanism of localized corrosion of Al MMC exists, there is sufficient evidence to show that $\mathrm{Al} / \mathrm{SiC}$ interface acts as a centre for localized corrosion and a reduction in the concentration of intermetallic compounds is accompanied by a reduction in localized corrosion as shown by the effect of tempers T4 and T6 on localized corrosion.

\section{Conclusion}

Based on the studies conducted in the last they decades, the following are the major conclusion on the mechanical and corrosion behaviour of Al MMCs

1. The mechanical properties of fiber, particulate, or whisker reinforced composites are strongly dependent upon the micro-structural parameters, size, shape, orientation and volume fraction of the reinforcement.

2. The tensile strength and Vickers micro-hardness increases significantly with increasing volume fraction of reinforcement as exemplified by Al6013, 6061, 2024 reinforced with particulate and whiskers. The strain to failure also decrease with increased volume fractions of reinforcement - Sliding velocity leads to lower wear rates and lower frication coefficient as shown by $\mathrm{SiC}$ and $\mathrm{B}_{4} \mathrm{C}$ reinforcements.

3. Increasing cutting speed increased tool wear. The highest wear rate was shown by 15 $\mathrm{wt} \% \mathrm{SiC}(\mathrm{p})$ and the lowest by $5 \mathrm{wt} \% \mathrm{SiC}$.

4. Because of accumulation of stress concentration and high dislocation density $\mathrm{Al} \mathrm{MMC's}$ are sensitive to stress corrosion cracking is $3.5 \mathrm{wt} \% \mathrm{NaCl}-\mathrm{Al} 6061 / 20 \mathrm{vol} \% \mathrm{SiC}(\mathrm{p})-\mathrm{T} 6$ shows a good resistance to stress corrosion cracking. The polarization curves shifted to higher current densities.

5. The corrosion rates of MMC's decreased with exposure time in long term immersion tests. Heat treatment lowered corrosion rates because of the homogeneous distribution of the precipitates an reduction in their concentration on the $\mathrm{Al} / \mathrm{SiC}$ interphase electrochemical studies on MMC's showed that the pitting potential decreased with increasing volume fraction of $\mathrm{SiC}(\mathrm{p})$ in $\mathrm{Al} 6013$ and 6061 reinforce with $\mathrm{SiC}$ particulate. Shallow pits contain intermetallic $\mathrm{CuAl}_{2}$.

6. The effect of machining conditions on corrosion showed that electrical discharge machining provided higher resistance to pitting than carbide turning or diamond turning machining.

7. The lowest rate of corrosion was shown by temper $\mathrm{T} 4$ if $\mathrm{A} 6013-20 \mathrm{SiC}(\mathrm{p})$ is $3.5 \mathrm{wt} \%$ $\mathrm{NaCl}$ containing silica and other particulate matter.

8. Studies in salt spray chamber showed a good resistance of MMC's to Corrosion and Heat treatment enhances corrosion resistance in corrosive environment.

9. MMC's exhibited a beneficial effect of inhibitor treatment with cerium chloride and sodium molybdate. Cerium Chloride has paved away more effective inhibition than sodium molybdate.

10. The mechanism of corrosion of MMC's is not conclusively understood. It has been, however, shown that the $\mathrm{Al} / \mathrm{SiC}$ interface us highly reactive due to the presence of intermetallic compounds. 


\section{References}

ASTM; Recommended Practice Designation G 31.72, Standard Practice for Laboratory immersion Testing, (2004) Vol 03, ASTM, Ohio, USA.

Aylor D. M, Moran P. I, Effect of Reinforcement on the pitting Behavior of Aluminum Based Metal Matrix Composites, Jr Electrochem Soc, (1986), Vol 30, p951.

Beccario A.M, Paggi G, Cingaud D, Castellor P, Silicon Carbide Alloy Metal Matrix Composites , Br Jr Corrosion, (1994), Vol 29(1), p65.

Beccario A. M, Poggi G. J, Ginguad D, Castello, Effect of Hydrostatic Pressure on Passivating Powder of Corrosion Layers Formed on 6061-T6 Aluminum Alloy in Sea, Br. Corros Jr, (1994), Vol 29, 1, pp 65-69.

Berkely, D.W, Sallam H.E, Nayeb. Hasemi, H, The effect of PH on the mechanism of Corrosion and Stress Corrosion and Degradation of Mechanical Properties of AA 6061 and Nextel 440 Fiber-Reinforced AA 6061Composites, Corros Sc,(1998), Vol 40, 2/3 pp, 141-153.

Burleigh T.D, Ludwiczak and Petro R.A, Itergranular Corrosion of an Aluminum Magnesium Silicon Copper Alloy, Corrosion Science, (1995), Vol 5199(1), p50.

Chen C, and Mansfeild F, Corrosion Protection of Al 6092/SiC (p) Metal Matrix Composite, Corr Sc, (1997), Vol 6, PP 1075-108.

Colman S. L, Scott V. D, Enaney M.C, Corrosion Behavior of Aluminum Based Metals Matrix Composites, (2011), Vol 297, 11, Dol: 10.10078/BF001117589, Jr of Mat Sc.

Davenport A. J, Isacs H. S, Kendig M. W; Investigations on the Role of Cerium Compound on the Corrosion Inhibition of Aluminum, Corrs Sc,(1991),Vol 32 (516), p653.

Dehlan Al Khalid; Hafeez Syed, Tensile Failure Mechanism of Al 6061Reinforced with Submicron Al2O3, AJSE, (2006), Vol 31, No 2C.

Feng.Z; Lin, C; LinJ; Lin j; Luo, J; “Pitting Behavior of SiC/2024 Al MMC”.

Griffen, A.J; Turnbull, A; 'An Investigation on the Electrochemical Polarization Behavior of Al6061 MMC' Corros Sc (1994), Vol 36,1, 21-35.

Hihara L. H, Corrosion of Metal Matrix Composites, Shriers Corrosion, (2010), Vol 3, pp 2250-2569.

Hinton B. R. W, Dr. Arnold Ryan N. E; Cerium Conversion Coating for Corrosion Protection of Aluminum, Mat. Forum, (1986), Vol 9(3), pp 162.

Hongho Ding, Hawthorn, G.A, Hihara, L.H, Inhibative Effect of Sea Water on the Corrosion of Particulate Reinforce Aluminium Matrix Composites and Monolithic Alloys, Jr. Electrochem Soc, (2009) 156, (100. (35).C159.

Isacs, H.S, Vyas, B; “Electrochemical corrosion Testing, ASTM, STP 727, 1981, p, 3.

Jamaludin, S.B, Yusoff Z, Ahmed R.R, Comparative Study of Corrosion Behavior of A.A. 2009/20 Vol\% SiC(w), Porpugaliay Electrochimica Acta, (2008), Vol 26, pp 291-301.

Lin, S; Shih, H; Mansfield F; Corrosion Protection of Aluminium Alloys and Metal Matrix Composites by Polymer Coatings; Corros Sc (1992), Vol 23, 9, pp 1331-1349.

Lin S, Greene H. Shih and Mansfeld F, Corrosion Protection of Al Metal Matrix Composites, Corrosion, (1989), Vol 45(8), p615.

Mansfield S, Lin S, Kim H, Shih, Pitting and Passivation of Al Based Metal Matrix Composites, J Electrochem Soc, (1990), Vol. 137, pp 75-82.

Mansfield F. S.L. Jeanjagnet; The Evaluation of Corrosion Protection Measures For Metal Matrix Composites, Corros Sc (1984), Vol 26, pp 727-734. 
Misra, Ajit Kumar, Balsubramanium, Corrosion Inhibition, Material Chemistry and Physics, (2007), Vol 103, 2, 3, pp 385-393.

Monticelli C, Zucchi C, Bruuonoro, Trabanelli C, Stress Corrosion Cracking Behaviour of some Aluminum Base Metal Matrix Composites, Corrs Sc, (1997), Vol 39,10, pp. 1949-1063.

Muhammad Ashraf, P. Leela Edwin, Evaluation of Corrosion Inhibition by Cerium on Aluminum under Marine and Laboratory Environment, 2nd Jr of Chem. Tech, (2004), Vol 11, pp 672-677.

Rohatgi, P.K; 'Aqueous corrosion of Metal Matrix Composites, Comprehensive Composite Materials, (2003), Chapter 3.18, , pp 481-500, Elsevier

Schwartz, M.M “Composite Material Processing Fabrication and Applications" Prentice Hall, USA (1997).

Shorowords,K.M; Haseeb, A.S.M.A; Celic,j.P; "Studies on the wear Friction and Tribochemistry of MMC Sliding against Phenolic Brake Pads, Wear" (2004), pp1176-1181

Turnbull, A.Br, Corros Jr 1992, Vol 27, p.27-35.

Trzskoma, P.P; in "Metal Matrix Composite Mechanism and Properties" Academic Press, (1991), p, 383.

Trazaskama P. P, Pit Morphology of Aluminum Alloy in Silicon Carbide Alloy Metal Matrix Composites, Jr Corrosion, (1990), Vol 46, p402.

Trazaskoma P.P, Maccefferty E, Crowe C.R, Corrosion Resistance of Al Based Metal Matrix Composites, Corrs Sc, (1990), 46, p402.

Vaeeresh Kumar, G.B., Rao, C.P; Selvararj.N; Bhagya Shekar, M.S.B; Studies on Al 6061-SiC and $\mathrm{Al}$ 7075-Al2O3 Metal Matrix Composite; Jr for Mater and Mater characterization and Eng, Nov (2010), Vol 9, pp, 43-55.

Vogelsang, M; Arsenault, R.J; Fisher, R.M; In SituHVEM study of Dislocation Generation of $\mathrm{Al} / \mathrm{SiC}$ Interface in Metal Matrix Composites, Met.Trans A, (1986), Vol 17A, p139.

Yue, T.M; Yu, J.K; Maki, H.G; “Corrosion Behavior of Aluminium 2009/SiC Composite Machined to Different Conditions". Jr Mat Sc Letters, (2002), Vol 21, 14, pp10691072

Yue, T.M; Wu, Y.X; Man, H.c; 'On the Role of CuAl2 Precipitates in Pitting Corrosion of Aluminium (2009), SiC Metal Matrix Composites' Jr of Materials Sc (2000), Letters 9, pp 1003-1006.

Zaki Ahmad and Abdul Aleem B. J, The Effect of Inhibitors on the Susceptibility of AL 6013, SiC Interface to Localized Corrosion, Jr of Mat Eng, Perf,(2009),Vol 18,2, pp129-136.

Zaki Ahmad, Mechanical Beauvoir and the Fabrication Characteristics of Aluminum Metal Matrix Composites, Jr of Reinforced Composite Material, (2007),Vol 1, 4, pp 30273033.

Zaki Ahmad, Abdul Aleem. B.J; Degradation of Aluminium Metal Matrix Composites in Salt Water and its Control, Mater and Design, (2001), Vol 23, pp173-180.

Zaki Ahmad, Paulette, P.T; and Aleem B.J.A; "Mechanism of Localised Corrosion of Aluminium Silicon Carbide Composites in a Chloride Containing Environment' Jr. Mat Sc (2000), 35, pp 2573-2579.

Zaki Ahmad \& Abdul Aleem B. J, Corrosion Resistance of a New Al 6013-20 SiC in Salt Spray Chamber, Jr of Mat SC and Eng, (2000), Vol 9, 31, p338. 
Zaki Ahmed \& Abdul Aleem B.J, Corrosion Resistance of New Aluminium Al 6013/20SiC(p) in Salt Spray Chamber,Jr Mat Sc and Eng,(2000),Vol 9(3),p338.

Zaki Ahmed, Paulette, P, T, Aleem B.J.A, Mechanism of Localize Corrosion of Aluminum Silicon Carbide Composites in Chloride Containing Environment, Jr Mater Sc,(2000), Vol 3, 5, pp2573-2579.

Zaki Ahmad \& Abdul Aleem B. J, The Erosion Corrosion of Al -SiC Composites in Sea Water, (1998), Final Report, KACST, 14-65, King Abdul Aziz City of Science and Technology, Riyadh, Saudi Arabia.

Lima, P.; Bonarini, A. \& Mataric, M. (2004). Application of Machine Learning, InTech, ISBN 978-953-7619-34-3, Vienna, Austria

Li, B.; Xu, Y. \& Choi, J. (1996). Applying Machine Learning Techniques, Proceedings of ASME 2010 4th International Conference on Energy Sustainability, pp. 14-17, ISBN 842-650823-3, Phoenix, Arizona, USA, May 17-22, 2010

Siegwart, R. (2001). Indirect Manipulation of a Sphere on a Flat Disk Using Force Information. International Journal of Advanced Robotic Systems, Vol.6, No.4, (December 2009), pp. 12-16, ISSN 1729-8806 


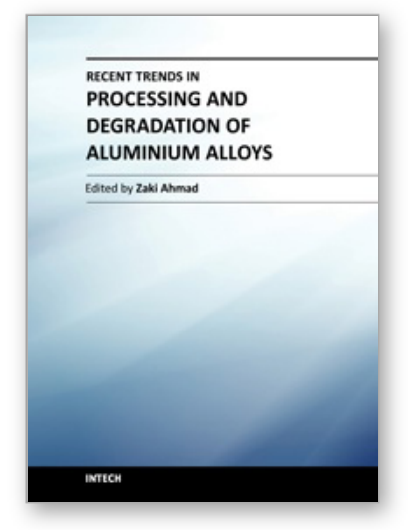

\section{Recent Trends in Processing and Degradation of Aluminium Alloys \\ Edited by Prof. Zaki Ahmad}

ISBN 978-953-307-734-5

Hard cover, 516 pages

Publisher InTech

Published online 21, November, 2011

Published in print edition November, 2011

In the recent decade a quantum leap has been made in production of aluminum alloys and new techniques of casting, forming, welding and surface modification have been evolved to improve the structural integrity of aluminum alloys. This book covers the essential need for the industrial and academic communities for update information. It would also be useful for entrepreneurs technocrats and all those interested in the production and the application of aluminum alloys and strategic structures. It would also help the instructors at senior and graduate level to support their text.

\section{How to reference}

In order to correctly reference this scholarly work, feel free to copy and paste the following:

Zaki Ahmad, Amir Farzaneh and B. J. Abdul Aleem (2011). Corrosion Behavior of Aluminium Metal Matrix Composite, Recent Trends in Processing and Degradation of Aluminium Alloys, Prof. Zaki Ahmad (Ed.), ISBN: 978-953-307-734-5, InTech, Available from: http://www.intechopen.com/books/recent-trends-in-processingand-degradation-of-aluminium-alloys/corrosion-behavior-of-aluminium-metal-matrix-composite

\section{INTECH}

open science | open minds

\section{InTech Europe}

University Campus STeP Ri

Slavka Krautzeka 83/A

51000 Rijeka, Croatia

Phone: +385 (51) 770447

Fax: +385 (51) 686166

www.intechopen.com

\section{InTech China}

Unit 405, Office Block, Hotel Equatorial Shanghai

No.65, Yan An Road (West), Shanghai, 200040, China

中国上海市延安西路65号上海国际贵都大饭店办公楼 405 单元

Phone: +86-21-62489820

Fax: +86-21-62489821 
(C) 2011 The Author(s). Licensee IntechOpen. This is an open access article distributed under the terms of the Creative Commons Attribution 3.0 License, which permits unrestricted use, distribution, and reproduction in any medium, provided the original work is properly cited. 